\title{
KÖY KORUCULARININ KÜRT SORUNU VE PKK ÖRGÜTÜ KONUSUNDAKİ GÖRÜŞLERİ ÜZERİNE SOSYOLOJIKK BİR ÇALIŞMA*
}

\author{
A Sociological Study on the Views of the Village Guards on the Kurdish Question \\ and the PKK Organization
}

\section{Zahir KIZMAZ ${ }^{1}$}

\section{Seyman ÖNDER ${ }^{2}$}

\section{ÖZET}

Bu çalışma, Doğu ve Güneydoğu Anadolu Bölgesinde görev yapan Geçici Köy Korucularının; Kürt sorunu ve PKK örgütü konusundaki yaklaşımlarını ele almaktadır. Korucuların PKK örgütünü, Kürt sorununun çözümünün bir aktörü olarak görüp görmedikleri, korucuların Kürt sorunu konusundaki yaklaşımlarının devletin ve PKK örgütünün bakış açısı ile ne düzeyde benzeştiği veya farklılaş̧ı̆̆ı hususunun araştırılması, bu çalışmanın temel problematiğini teşkil etmektedir. Çalışmada, korucuların Kürt sorununu ağırlıklı olarak "anadilde eğitim” temelinde tanımlamakla birlikte, PKK'nn dış güçler tarafindan kullanılan bir terör örgütü olduğunu (\% 68) ve dolayısıyla Kürt sorunu ile ilintili ele alınamayacağı yönünde görüşler belirttikleri tespit edilmiştir. Kimi korucuların da (\% 20. 4’ü), PKK örgütüne yönelik yaklaşımlarının, örgütü destekleyici ve meşru olarak tanımlayıcı bir içerikte olduğu yönünde sonuçlar elde edilmiștir. PKK örgütünü olumlu değerlendiren koruculardan bazılarının da demokratik özerklik modeline sıcak baktıkları dikkat çekmiştir. Kürt sorununun varlı̆̆ını kabul eden korucuların öne çıkardıkları ana tema ise, bu sorunun şiddet eylemleri ile çözülemeyeceği hususu oluşturmaktadır.

\section{Anahtar Kelimeler: Köy Korucuları, Kürt Sorunu, PKK Örgütü}

\section{ABSTRACT}

This study deals with the approaches of temporary village guards who served in the Eastern and Southeastern Anatolia Region on the Kurdish Question and PKK (Kurdistan Workers' Party). Whether or not the village guards consider the PKK as an actor in solving the Kurdish problem and to what extent their approach on the issue looks like or differs from those of the State and PKK are the main problematics of the study. In the study it has been found that the village guards identified the Kurdish question on the basis of "education in mother tongue", stated (\% 68) that PKK is a terrorist organization used by external forces and hence it could not be addressed in connection with the Kurdish question. It has been found that some village guards (\% 20.4) had supportive and legitimising approaches to the PKK organization. It is remarkable that some of the village guards who were positive about the PKK organization approved the democratic autonomy model. The main theme featured by the village guards who accepted the existence of the Kurdish question was that the problem could not be solved by means of violence.

Key Words: Village Guards, Kurdish Question, PKK Organization

\section{GİRiş}

Köy koruculuk sistemi ilk kez 1924 y1lında çıkartılan 442 sayılı Köy Kanunu'nun 74. Maddesi ile gündeme gelmiştir. Bu maddede köy kuruculuğu, "çapulcular ve eşkıya türemiş ise köy halkını yağmadan korumak için köylünün eli silah tutanlardan" oluşan bir yerel güvenlik birimi olarak ifade edilmiştir. Yeni kurulan Türkiye Cumhuriyeti'nin güvenlik teșkilatının etkisinin ağırlıklı olarak merkezle sınırlı kalması ve örgütlülügün taşrada tesis edilememesi, yeni hükümetin güvenlik

${ }^{*}$ Bu çalışma, Fırat Üniversitesi Sosyoloji Bilim dalında yapılmış olan "Geçici Köy Korucuları Üzerine Sosyolojik Bir Araştırma" başlıklı doktora tezinde kullanılan verilerden sınırlı düzeyde yararlanılarak hazırlanmıştır.

${ }^{1}$ Prof. Dr. Zahir KIZMAZ, Fırat Üniversitesi İnsani ve Sosyal Bilimler Fakültesi Sosyoloji Bölümü ELAZIĞ e-mail: zkizmaz@,firat.edu.tr

${ }^{2}$ Yrd. Doç. Dr. Bingöl Üniversitesi Fen-Edebiyat Fakültesi BİNGÖL e-mail: onderseyman@gmail.com 


\section{F.Ü. Sosyal Bilimler Dergisi 2016-26/1}

teşkilatının nüfuzunun sınırlı kalmasını doğurmuştur. Bu çerçevede taşrada, eşkıya ve çete benzeri oluşumlarla etkin mücadele etmede yeni yönetimin yetersiz kalmasının yol açtığı güvenlik sorunlarının, yerel halkın silahlandırılması ile aşılabileceği düşüncesi böyle bir düzenlemenin gerçekleştirilmesinin temel nedenini teşkil etmiştir. Köy kuruculuğu sistemi olarak tanımlanan bu yeni sistemin geliştirilmesi ile gerek bireylerin yasal bir korumaya kavuşmaları gerekse de devletin taşrada güvenlik gücünü tesis etmesi ve şiddet kullanma tekelini oluşturması sağlanmıştır. 1930'l1 yılların sonlarına kadar aktif olarak kullanılan köy koruculuğu sistemi, jandarma teşkilatının kırsal alandaki örgütlenmesini tamamlamasıyla birlikte her ne kadar da köy koruculuğu yasal olarak yürürlükten kaldırılmamış olsa dahi, 80'lerin ortalarına kadar fiilen uygulanmadığı gözlenmiştir (Paker ve Akça, 2013: 7-8).

Köy koruculuğu sistemi, PKK örgütünün devlet güçlerine yönelik silahlı eylemlerini başlattığı 1984 y1lından sonra yeniden gündeme gelmiştir. Köy koruculuğu sistemi kırsal bölgelerde, terör olaylarının yoğunluk kazanması üzerine asayiş ve güvenliği sağlama adına, yukarıda belirtilen Köy Kanunu ve Orman Bekçiliği yasalarından devşirilerek yeniden formüle edilmiştir. Bu nedenle bu çalı̧̧mada konu edilen koruculuk sistemi, PKK örgütüne yönelik olarak güvenlik politikalarının bir sonucu olarak, PKK örgütü ile etkin mücadele edebilmek amacıyla geliştirilmiştir.

26 Mart 1985 tarih ve 3175 sayılı yasa ile kabul edilen geçici köy koruculuğu yasası 27 Haziran 1985 tarihinde de uygulamaya geçmiştir. Bu kapsamda 90'li yıllarda sayıları 80 bini bulan korucuların sayıs1, 2006'ya gelindiğinde 57 bine düşmüştür (bkz. Kurban, 2010: 255; Paker ve Akça, 2013: 8). Köy korucularının sayıları, yıllara göre farklılık göstermiştir. Bu farklılıklar, dönemin siyasi konjonktürü ve güvenlik politikalarına paralel bir seyir izlemesi ile ilintili olarak gerçekleşmiştir. Bir anlamda, çatışmaların yoğunluklu yaşandığı dönemlerde korucu olma oranlarında artış, çatışmaların azaldığı dönemlerde ise, azalmalar gerçekleşmiştir.

Köy koruculuk sisteminin oluşturulduğu 1985 yılından günümüze kadar sisteme dâhil olmuş toplam korucu sayısının, 129 bin 273 olduğu rapor edilmiştir. Günümüzde ise geçici köy korucusu sayısının, yaklaşık 65 bin 487 olduğu belirtilmektedir ${ }^{1}$. Bunların, 20 bin 204'ü gönüllü köy korucusudur. 2009 yılı verilerine göre korucular, ağırlıklı olarak en çok Hakkâri (7 bin 614), Van (7 bin 320), Şırnak (6 bin 756), Diyarbakır ( 5 bin 187), Siirt (4 bin 661), Bitlis (3 bin 730), Mardin (3 bin 323), Batman (2 bin 887), Bingöl (2 bin 511), Elazı̆g (2 bin 111), Muş (bin 881) illerinde yoğunlaşmışlardır.

Özellikle 90’lı yıllardan sonra PKK örgütünün güçlenmesi, halk desteğinin artması, PKK örgütüne katılımların artması, örgütün eylem yapma kapasitesindeki artışlar ve daha geniş bir coğrafyada eylem yapabilirlik olanağına sahip olmaları, örgüt sempatizanlarının ve toplumsal desteğin arttığı bölgelerde koruculara yönelik giderek artan eleştiriler ve olumsuz bakışlar, kimi korucuların silah bırakma yönünde karar almalarına yol açmıştır. Kimileri de devlet yetkilileri ve aşiret liderlerinin ikna edici çalışmaları sonucunda istifa etme kararlarından vazgeçmeleri sağlanmıştır.

PKK örgütü, köy koruculuk sisteminin oluşturulmasının akabinde, korucu olanların devletle işbirliği yapacakları ve bu nedenle hain olarak ilan edilecekleri yönünde açıklamalar yapmış ve sonraki dönemlerde köy korucularına ve yerleşim yerlerine yönelik saldırılar gerçekleştirmiştir. 2530 Ekim 1986 tarihleri arasında örgütün gerçekleştirdiği 3. Kongresinde köy korucularının ve işbirlikçilerinin cezalandırılacağı yönünde kararlar almıştır. Örgütün bu ve sonraki dönemlerde aldığı kararlar sonucunda gerçekleştirdiği saldırılarda çok sayıda korucu öldürülmüştür.

PKK örgütü, koruculuk sisteminin oluşturulmasından sonra, devlet ile mücadele süreçlerinde önlerinde önemli bir engel olarak gördüğ̈̈ için korucu olmayı kabul edenleri hedefine koymuştur. Örgüt, sık sık korucu köylerine saldırılar düzenleyerek, korucu olmayı bölgede cazip bir tercih

\footnotetext{
${ }^{1}$ Bu veriler 2012 yılına ait olup, Jandarma Genel Komutanlığından kişisel yazışma yoluyla alınmıştır.
} 
olmaktan çıkarmayı hedeflemiştir. PKK 1986 yılında, III. Kongresinde köy korucularının ve yakınlarının öldürülmesi, evlerinin kundaklanması ve mallarının yağmalanması kararını alınmıştır (İmset, 1993: 141). Koruculuk sistemi oluşturulduğu tarihten bu yana PKK ile mücadelede etkin rol oynamış ve bu nedenle devlet güvenliğine büyük katkı sağlamıştır. Korucuların, PKK örgütü ile olan bu çatışmalarda (Mayıs 2012 yılına kadar), 1578'i hayatını kaybetmiş, 1765'i de yaralanmıştır (JGK, kişisel yazışma, 2012). PKK'nın köy korucularına yönelik saldırıları veya korucuların, PKK'nın hedefi olabilecekleri korkusu sonraki dönemlerde korucu olmalarında caydırıcı bir unsur olarak belirleyici olmuştur (bkz. Paker ve Akça: 21). Örgüt geçmiş dönemlerde, bir yandan korucu köylerine yönelik saldırılar gerçekleştirmiş, yol kontrollerinde köy korucularını kaçırmış veya öldürmüş, öte yandan da koruculuk görevlerini bırakma yönünde çağrılar yapmıştır. PKK, koruculara yönelik bir yandan fiziksel saldırılarda bulunurken öte yandan da, "hain Kürt', 'işbirlikçi Kürt' ve eşek yavrusu anlamında "cahş" şeklinde yaftalayarak, bölge halkı nezdindeki itibarlarına gölge düşürmek, onları aşağılamak ve toplum tarafindan dışlanmalarını sağlamak mücadelesini vermiştir. Koruculara yönelik saldırıların yanı sıra zaman zaman da silahlarını bırakanlara karşı "af" ilan etme yoluna gitmiştir.

PKK'nın, koruculara yönelik tutumu, 1994 yılından sonra belli oranda değişme eğilimi göstermiştir. İlk dönemlerde, korucuları asıl hedef olarak gören PKK, sonraki yıllarda sert tutumunda kısmen de olsa bir yumuşama göstermiştir. PKK ve onların bileşenleri tarafindan koruculuk sistemi "Kürdün Kürde kırdırılması" olarak görülmüş, örgüte karşı operasyonlara çıkmadıkları, onları ihbar etmedikleri ve devlet ile işbirliği yapmadıkları müddetçe korucularla çatışmaya girmekten ve onlara saldırmaktan kaçındıkları yönünde yeni bir strateji benimsenmiştir. $\mathrm{Bu}$ dönemde ayrıca, örgüt korucularla gizli işbirlikleri gerçekleştirmek için de zaman zaman çabalar sergiledikleri bir gerçektir.

Devletin güvenlik güçleri ile birlikte PKK ile mücadele eden korucuların, PKK ve Kürt sorunu konusunda ne düşündüklerinin tespit edilmesi önemlidir. Örgüt ve sempatizanlarının, korucular hakkındaki görüşleri genelde onların "hain, işbirlikçi” oldukları çerçevesinde yoğunlaşmaktadır. PKK'nın korucuları toplum nezdinde itibarsızlaştırma girişimlerinde bulunmalarına rağmen bazı korucuların, PKK ve Kürt sorununa bakış açılarının devletin yaklaşımından farklı olabileceği varsayılmaktadır. $\mathrm{Bu}$ nedenle zaman zaman, PKK örgütüne yardım ve yataklık suçundan soruşturma geçiren köy koruculara ilişkin haberler medyaya yansımaktadır. Bu çerçevede ağırlıklı olarak Kürt kökenli olan korucuların, Kürt ve PKK sorununu nasıl değerlendirdikleri hususunun irdelenmesi bu çalışmanın temel sorunsalını oluşturmaktadır.

$\mathrm{Bu}$ çalışmada, ilkin bireylerin korucu olmayı kabul etme nedenleri ele alınacak akabinde de korucuların Kürt sorunu konusunda ne düşündükleri, nasıl bir yaklaşım içerisinde oldukları ve PKK örgütüne bakış açıları, onlarla mücadele etmeyi nasıl tanımladıkları gibi konular açıklanmaya çalışılacaktır. Koruculuğu kabul etme nedenlerinin bilinmesi, korucuların Kürt sorunu ve PKK örgütüne bakışının farklılaşmasında açıklayıcı bir çerçeve sunup sunmadığını bilinmesi açısından önem arz etmektedir.

\section{KORUCULUK SISTEMININ GELISSTIRILMESİ VE KORUCU OLMA NEDENLERİ}

Devletin PKK örgütüne karş1 köy koruculuğu sistemini geliştirmesinin çeşitli nedenleri bulunmaktadır. Paker ve Akça (2013: 11-12)'ya göre üç temel faktör öne çıkmaktadır: Birincisi; devlet yetkililerinin ilk silahlı eylemlerine başladığı dönemde PKK örgütünü bir avuç eşkıya olarak tanımlaması ve Türk Silahlı Kuvvetlerinin (TSK) bu örgüte karşı mücadele edebilme konusunda yaşadığı güçlüktür. Diğer bir ifade ile ordunun ilk dönemlerde, "küçük çaplı gerilla hareketliliğiyle mücadele edebilme kapasitesinin" düşük olmasıydı. İkincisi, merkezi devletin ve TSK mensuplarının, bölgenin coğrafik yapısı hakkında yeterli bilgiye sahip olmamaları ve dolayısıyla ordunun/güvenlik güçlerinin, yabancisı olduğu bir bölgede PKK örgütü mensuplarıyla mücadele etme konusunda yaşayacağı zorluklardır. Bu çerçevede güvenlik birimlerinin, Köy Korucularıyla yapacakları bilgi alışverişinin ve operasyonların daha başarılı olacağına dair yaklaşım, köy 


\section{F.Ü. Sosyal Bilimler Dergisi 2016-26/1}

koruculuğu sisteminin geliştirilmesinin önemli bir nedenini oluşturmuştur. Üçüncü neden ise, devlet açısından bu sistemin köy korucuları üzerinden PKK örgütü ile mücadele sürecinde yanında veya karşısında olabilecek olan güçleri tanımlama gibi operasyonel bir işlevi görmeye yaramış olmasıdır. Yerel güç odakları ile gerçekleştirilebilecek işbirliği bu anlamda "safinı belirleme" ve nerede durduklarına ilişkin mesaj verme gibi önemli bir işlevi yerine getirmiştir. Daha genel bir bakışla koruculuk sisteminin geliştirilmesinin önde gelen nedenleri arasında; kurulduğu yıllarda ordunun bölgeyi tam olarak bilmemesi, yeteri kadar hılı hareket edememesi, ordunun gerekli teknolojik donanımdan yoksun olmas1, etkin bir mücadele stratejisini uygulamada zafiyetler yaşaması, halkın terörle mücadelede yer almasının sağlanması (Fuller ve Barkey, 2011: 214) ve bölge insanı için yeni bir istihdam imkânı veya geçim kaynağı yaratmış olması (Tüysüz, 2014:188) gibi hususları saymak mümkündür (Fuller ve Barkey, 2011: 214).

Bölgede bireylerin veya aşiretlerin koruculuğu kabul etmelerinde ise çok sayıda neden etkili olmuştur: Çoğu bölgede koruculuğun bir aşiret kararı olarak kabul görmesi, PKK örgütünün ciddi toplumsal desteğe sahip olmadığı ilk dönemlerde maaş sahibi olmanın karlı bir geçinme stratejisi olarak değerlendirilmiş olması (sosyo-ekonomik gelişmişlik açısından bölgenin en alt sırada yer alması, yoksulluk ve işsizliğin yaygın olarak gerçekleştiği bölge olması) veya PKK örgütünün etkisinin sadece belirli bölgelerle sinırlı olabileceği öngörüsü, koruculuğu kabul eden bazı aşiretlerin PKK örgütü ile geçmişten gelen düşmanlıkları, köy boşaltılmasının önüne geçme anlayışı, devlet olanaklarından yararlanma beklentisi, hukuki dokunulmazlık ve devletin yanında olmanın ayrıcalığını/imtiyazını elde etme isteği, örgütün aşireti tasfiye edeceği yönündeki propagandaların ${ }^{3}$ etkisi gibi hususlar, koruculuğun bireyler veya aşiretler tarafindan kabul edilmesini sağlamıştır. Özellikle koruculuk sisteminin geliştirildiği dönemlerde, devlet görevlilerin korucu olmaları yönünde görüş̧ükleri aşiret liderlerinin bu teklife olumsuz yaklaşmalarının, devlet karşıtı bir tutum olarak yorumlanabileceği korkusu onların koruculuğu kabul etmelerinde önemli bir faktör olmuştur. Ancak sonraki süreçlerde PKK'nın koruculara yönelik kapsamlı saldırıları ve bu saldırılarda yaşanan can kayıpları, aşiret ve akrabalık bağının güçlü olduğu bazı bölgelerde bireylerin koruculuğu kabul etmelerini etkilemiştir. Devlet nezdinde ayrıcalıklı olma, devlet tarafindan ödüllendirilebilecekleri beklentisi, sorunlu oldukları diğer aşiretlere karşı daha güçlü bir pozisyona yükselme (kan davası, arazi anlaşmazlıkları v.b. geçmişten gelen çatışmalardan dolayı diğer aşiretlere karşı daha imtiyazlı ve güçlü bir konum elde edecekleri beklentisi (bkz. Barkey ve Fuller, 1998: 147), ilk dönemlerde askeri ve sivil otorite yetkililerinin kısmi zorlamaları ${ }^{4}$ (köy boşaltmalarının önüne geçme, ikna çabaları gibi) aşiret liderlerinin koruculuğu kabul etmelerinde etkili olan diğer nedenleri oluşturmaktadır. Paker ve Akça'nın (2013: 22) da belirttikleri gibi aşiret yapılarının etkin ve güçlü olduğu ve devlet ile geçmişe dayalı güçlü bir ilişkinin olduğu bölgelerde, koruculuk sisteminin benimsenmesi veya destek bulması daha kolay olmuştur. Bir anlamda, aşiretlerin koruculuğu benimsemiş olmalarının önemli bir nedeni, korucu olmayı benimsemekle devletin yanında olduklarını göstermek ve aynı şekilde bunun getirisi olarak ödül beklentisini karşılamak ve kabul etmeme durumunda ortaya çıkabilecek olası risklerden muaf olmaktır. Burada ödül ve ceza denkleminin kullanışlı bir açıklama modeli olarak öne çıktığı görülmektedir. Önder (2013) da, "Geçici Köy Korucuları Üzerine Sosyolojik Bir Araştırma" başlıklı doktora tez çalışmasında koruculuğun kabul edilme nedenleri olarak; devlet baskısı' (\% 33,9), “ekonomik nedenler" ( \% 33.5), "PKK baskısı" (\% 24,9), "köyün güvenliğini sağlamak", (\% 24.9), "başka aşiretlere karşı güçlü kalabilmek' (\% 11,4) ve 'devlete hizmet edebilmek” (\% 11,4) şeklinde belirtilen gerekçeleri saptamıştır. Önder, korucularla yaptığı enformel görüşmelerde yukarıda belirtilen etkenlerin dışında; köylerini terk etmeme isteği, rakip köylerin koruculuğu kabul

\footnotetext{
${ }^{3}$ PKK, aşiret yapılarını sömürgeci iktidarın işbirlikçileri olarak tanımlayıp, feodal yapının uzantısı olan bu yapının tasfiye edileceğine dair geçmişte ciddi propagandalar yaptığı bilinmektedir.

${ }^{4} 1989$ yllında Van ilindeki görüşmelerdeki, aşiret liderleri ile devlet görevlileri arasında yaşanan tartışmalar için bkz. Tüysüz, 2014:181.
} 
etmeleri, aşiret bağlayıcılığı, PKK'yı desteklemediğini gösterme, devletin desteğini arkalarına alma ve ekonomik güçlükler gibi başka faktörlerin de etkili olduğunu tespit ettiğini belirtmektedir.

Tüysüz (2014) de, Güneydoğu Anadolu Bölgesinde yer alan bir köy örneğinde ${ }^{5}$ koruculuğun kabul ve yaygınlaşması kapsamında yaptığı çalışmada, koruculuğu kabul etme veya korucu olmanın kişisel gerekçelendirme nedenleri olarak şu hususları saptamıştır. Aşağıda belirtilen faktörler bir anlamda konuyu özetler durumdadır:

1. Ekonomik gerekçeler (maaş sahibi olma gibi)

2. Politik tercihler (Apoculuğun ve Kürtçülüğün sevilmemesi),

3. Savunmasızlık hissi (PKK saldırıları karşısında silahlı bir güç olma),

4. Güvenlik güçlerinin baskısı (koruculuğu kabul etmeleri gerektiği yönündeki ikna edici ve zorlayıcı çabalar),

5. Aşiretlerin veya ailelerin güçlü bir konum elde etme isteği,

6. Koruculara sağlanan imtiyazların cazibesi (ayrıcalıklar ve dokunmazlıklar gibi),

7. Yeniden çerçevelenen geleneksel düşmanlıklar (kan davaları, arazi anlaşmazlıkları gibi aşiretler arasında geçmişten gelen düşmanlıklarda üstün/ayrıcalıklı bir pozisyon elde etmek).

Koruculuk sisteminin geliştirildiği ilk dönemlerde korucu olmayı kabul edenlerin sorumluluk alanı ağırlıklı olarak, örgüt elemanlarının kırsal bölgelerdeki yerleşim bölgelerinden lojistik destek almalarını engellemek ve örgüt elemanlarına karşı yerleşim bölgelerini korumak şeklinde sınırlandırılmışken, sonraki dönemlerde korucuların görev alanları kolluk kuvvetleri ile birlikte operasyona çıkmayı da içerecek şekilde genişletilmiştir.

\section{ARAŞTIRMANIN YÖNTEMINE İLIŞKİN BAZI BÍLGILER}

$\mathrm{Bu}$ makalede korucuların, koruculuğu kabul etme nedenleri ve PKK ile Kürt sorunu konusundaki görüşleri ele alınmıştır. Araştırmanın evrenini, Doğu ve Güneydoğu Anadolu Bölgesinde görev yapan Geçici Köy Korucuları teşkil etmektedir. Araştırma kapsamında, 18 korucu ile derinlemesine görüşmeler yapılmıştır. 245 korucuya da, "PKK örgütünü nasıl değerlendiriyorsunuz?", "PKK ile mücadeleyi doğru buluyor musunuz" şeklinde sorular yöneltilmiştir. Arıca, araştırma kapsamında görüşülen suçluların bazı sosyo-demografik ve ekonomik özellikleri belirlenmeye çalışılmıştır. Görüşme yapılan koruculardan aşağıdaki sorulara yanıt verilmeleri istenmiştir.

1. Sizce bir Kürt sorunu var mıdır? Eğer size göre bir Kürt sorunu varsa, bu sorunu nasıl tanımliyorsunuz?

2. Anadilde eğitim, özerklik ve hükümetin Kürt sorununa bakışı konusunda neler düşünüyorsunuz?

3. Size göre Kürt sorunu varsa, bu sorun nasıl çözülür?

4. PKK örgütünü nasıl değerlendiriyorsunuz?

5. Bazı korucuların, PKK'ya yardım ve yataklık etme nedenleri ne olabilir?

$\mathrm{Bu}$ araştırmanın uygulamalı kısmı olan korucular ile olan görüşmeler, devlet yetkililerinin, PKK örgütü ile müzakere süreçlerini yürüttüğü dolayısıyla çatışmaların çok daha az düzeyde gerçekleştiği 2012-2013 yılları arasında gerçekleştirilmiştir. Dolayısıyla, araştırmanın görüşmeleri, PKK örgütünün kentlerde özyönetim ilan ettiği ve belirli yerleşim yerlerinde barikat ve hendekler kazmaya başladığı yoğun çatışmalı dönemden önce yapılmıştır.

\footnotetext{
${ }^{5}$ Köyün ismi belirtilmemiştir. Sadece Ademli köyü olarak belirtilmiş ve bu da köyün gerçek ismi değildir.
} 


\section{F.Ü. Sosyal Bilimler Dergisi 2016-26/1}

\section{ARAŞTIRMANIN BULGULARI}

\section{1. Örneklem Grubunun Sosyo-Demografik Özellikleri}

Araştırma kapsamında görüşülenlerin hepsi erkek bireylerden oluşmaktadır. Köy korucuları en çok 46-50 yaş arasında yoğunlaşmıştır $(\%$ 27,8). Genel olarak değerlendirildiğinde, araştırma kapsamında görüşülen korucuların sadece \% 17'sinin 35 yaşın altında oldukları, geriye kalan \% 83 'ünün de, 35 yaş üstü yaş kategorilerinde yer aldıkları görülmektedir. Bu durum, korucuların yaş ortalamalarının oldukça yüksek olduğunu ortaya koymaktadır.

Korucuların sadece \% 29'ü, ortaokul ve lise mezunu oldukları, \% 71'inin ilkokul mezunu ve her hangi bir okul mezun olmadıkları tespit edilmiştir. Sadece okur yazar ve dolayısıyla her hangi bir ilkokul mezunu olmayanların oranı \% 27.3 olarak tespit edilmiştir. Bu oranlar, korucuların yaklaşık olarak üçte birinin hiçbir öğrenim görmediği, üçte birinin de ilkokul mezunu olduğunu göstermektedir. $\mathrm{Bu}$ da, korucuların öğrenim düzeylerinin son derece düşük olduğunu göstermektedir. Korucuların \% 98,8'i evli, \% 1,2'si ise (üç kişi) bekâr olduklarını belirtmişlerdir. Bunların \% 94'ünün tek eşli, \% 4'ünün de çift evli oldukları belirlenmiştir. Korucuların \% 34,6's1, 8 ve daha fazla çocuğa sahip olduklarını belirtmişlerdir. 2 ve 2 'den daha az çocuğu olduğunu belirtenlerin oran $1 \% 8$ iken, 3 ve 3'ten daha fazla çocuk sahibi olduklarını belirtenlerin oranı $\% 92$ olarak tespit edilmiştir. Hane üye sayılarının ortalamasının da, 8,5 düzeyinde olduğu bulgusu elde edilmiştir.

Korucuların maaşı, araştırmanın gerçekleştirildiği yıldaki asgari ücrete yakın bir değerde olduğu tespit edilmişti ${ }^{6}$. Korucuların, asgari ücretle birlikte zaman zaman operasyon tazminatı da aldıkları ancak bu ücretin de maaşın dörtte birini geçmediği ifade edilmiştir.

Araştırma kapsamında görüşülen korucuların \% 9’u, 1985 - 1989, \% 59,6's1 1990 -1994 , \% 23,7'si 1995-1999, \% 1,2'si 2000-2005 ve \% 6.5'i de 2005-2011 y1lları arasında korucu olduklarını belirtmişlerdir. Belirli yıllarda korucu olma oranlarında gerçekleşen artışın nedeni, bu dönemlerde PKK örgütü ile çatışmaların daha yoğun olarak yaşanmış olmasıdır. Özellikle koruculara olan gereksinim, çatışmaların yoğunlaşması ile birlikte artış eğilimi göstermiştir.

\subsection{Korucuların Kürt Sorunu Konusundaki Yaklaşımları}

Geçici Köy Korucularının "Sizce bir Kürt sorunu var mıdır?" şeklindeki soruya verdikleri yanıtlar, bu konuda farklı görüşlere sahip olduklarını ortaya koymaktadır. Koruculardan önemli bir oranı, "Kürt sorunun" varlığını kabul ederken, kimi korucular da böyle bir sorunun varlığını reddetmişlerdir. Kürt sorunun varlığını kabul eden kimi korucuların Kürt sorunu hakkındaki görüşleri, Kürtlerin etnik ve demokratik hakları için mücadele ettiğini belirten Kürt siyasi aktörlerinin ve STK' larının yaklaşımından çok da farklı olmadığı belirlenmiştir. Bu çerçevede; bazı korucular, Kürt sorununun, Cumhuriyet döneminden bu yana sürüp geldiği bilgisini paylaşmışardır. Ancak korucuların önemli bir oranı, Kürt sorunun varlığını kabul etmekle birlikte son dönemlerde hükümetin bu sorunu çözme konusunda gerçekleştirdikleri reformlara dikkat çekmişlerdir ${ }^{7}$.

\subsubsection{Kürt Sorunun Varlığını Kabul Eden Korucuların Görüsşleri}

Korucuların, kendilerine yöneltilen, "size göre bir Kürt sorunu var mı, varsa bu sorun nedir veya bu sorundan ne anlıyorsunuz?" şeklindeki sorulara verdikleri yanıtlardan sadece birkaçı aşağıya alınmıştır:

"Evet, elbette bir Kürt sorunu var. Kürtler bazı haklarından yoksun birakıldılar ve bu durum Cumhuriyet'ten beri devam ediyor. Kürtlerin hakları konusunda bazı iyileştirmeler yapıld. Eğer bu iyileştirmeler devam ederse ve bölgenin ekonomik gelişimi için bir seferberlik başlatılırsa bu sorun çözülür sanıyorum. Hükümetin bu konuda birtakım çabalarl var ve bunlar olumlu şeyler, ama yetersiz. Hükümetin biraz daha kararlı olması gerekmektedir." (1. Görüşmeci)

\footnotetext{
${ }^{6}$ Çalışmanın yapıldığı dönemde (2012) asgari ücret net 701.14 TL. tutarındaydı.

${ }^{7}$ Hükümetin geçmiş dönemlerdeki demokratik reformlarına dikkat çekilmektedirler.
} 
Yukarıdaki alıntıda, Kürt sorunun varlığının veya Kürtlerin bazı haklardan yoksun bırakılma tarihinin Cumhuriyetin kuruluş dönemine kadar uzandığı, ancak son dönemlerde hükümetin Kürt sorununu çözümü konusunda girişimlerinin olduğu ancak bu girişimlerin yetersiz olduğu, sorunu çözme çabalarının devam etmesi gerektiği ifade edilmiştir. Burada dikkat çekilen diğer bir husus ise, Kürt sorunun çözümüne ekonomik gelişimini de gerekliliğinin dâhil edilmiş olmasıdır.

"Evet, bana göre bir Kürt sorunu vardır........ Ancak bu sorun, örgütle, silahla çözülebilecek bir sorun değildir. Bu işe ancak siyasiler ve aydınlar bir çözüm bulabilir. Hükümeti bu konuda destekliyorum. Bu yönde önemli çabaları söz konusudur. Ancak onların da önlerine geçen ve çözüme engel olmak isteyen bazı çevreler var. Bunlar, rantları ve çıkarları için çaba gösteriyorlar" (2. Görüşmeci)

$\mathrm{Bu}$ alıntıda, sorunun varlığı kabul edilmekle birlikte çözümün şiddetle ve PKK örgütü ile gerçekleşmeyeceği; hükümetin demokratik reformlarının, siyasal aktörlerin ve aydınların girişimlerinin olası olumlu katkılarına gönderme yapılmıştır.

“Elbette bir Kürt sorunu vardır. Dilimiz ve kültürümüz yasaklanmıs. Dilimiz kaybolmaya yüz tutmuş, çocuklarımız ne Kürtçeyi ne de Türkçeyi tam konuşabiliyor. Diğer ülkelerdeki Kürtler de hesap edilerek bu soruna çözüm aranmalıdır. Sadece Türkiye'deki Kürtler açısından bakılmamalıdır. Hükümet Kürt meselesini, temel sorunlarına değil de daha hafif sorunlara yönelik tavizler vererek sakinleştirme yoluna gidiyor. Ama bu durum ileride daha büyük sorunlara neden olacaktır" (3. Görüşmeci)

Kürt sorunun varlığının kabul edildiği yukarıdaki alıntıda, Kürt sorunun sadece dil çevresinde tanımlanmadığı, Türkiye dışındaki ülkelerdeki Kürtleri de içeren bir çözüm perspektifi dile getirilmiştir. Diğer ülkelerdeki Kürtleri de kapsayan bir çözümün, Kürtlerden teşekkül eden ayrı bir oluşum veya devlet imasını içerdiği söylenebilir. Bu nedenledir ki, hükümetin Kürt sorununun çözümü konusunda ortaya koyduğu performansın, asıl soruna odaklanmadığı ve uyutma politikasının bir parçası olduğu değerlendirmesi yapılmıştır.

Yapılan görüşmelerde Kürt sorunun varlığını kabul ettiğini belirten korucular ağırlıklı olarak; cumhuriyet döneminden bu yana bir Kürt sorunu olduğunu, bu sorunun da en belirgin göstergesinin Kürt dilini kullanma yönündeki engeller olduğunu dile getirmişlerdir. Bunun yanı sıra, Kürt sorunu ile ilintili olarak kimi korucular Kürtlerin geçmişte ikinci sınıf vatandaş muamelesi gördükleri ve asimilasyona tabi tutulduklarını ileri sürmüşlerdir.

Ancak korucuların çoğunun dile getirdikleri ortak bir tema ise, Kürt sorununun şiddet eylemleri ile çözülemeyeceği ve hükümetin bu sorunu çözme konusunda sergilediği tutumun olumlu olduğu - her ne kadar da kimileri bu çalışmalara yeterli görmezse veya çıkabilecek engellemeler konusunda tedirginlik hissetseler de- yönündedir.

Kürt sorunu, son dönemlerde en çok anadilde eğitim ve özerklik talebi alanında yoğunlaşmış durumdadır. Korucuların, anadilde eğitim ve özerklik talepleri konusundaki görüşleri de homojen bir nitelik arz etmemektedir. Korucuların çoğu, anadilde eğitimin olanaklı hale gelmesini sağlayacak yasal düzenlemelere olumlu bakarken, özerklik konusunda aynı düzeyde olumlu yaklaşımın olduğunu söylemek mümkün değildir. Diğer bir ifade ile demokratik özerklik talebi anadilde eğitim talebine kıyasla daha az arzulanmaktadır. Kimi korucuların anadil ve sayıca çok az da olsa bazı korucuların özerklik talebi yönündeki görüşleri aşağıya alınmıştır:

"Benim çocuklarımın ve bundan sonra gelecek nesillerin dillerini bilme, ögrenme ve ögretme haklarl vardır. Bu, hem dini, hem insani, hem de İslami yönden meşrudur. Özerklikten istenen, federatif bir yönetim ise buna gerek olmayabilir. Ama her şeyin merkezden kontrol edilmesine de gerek yoktur. Bazı konularda merkezi yönetimin kararını beklemek gereksizdir.”' 1. Görüşmeci) 


\section{F.Ü. Sosyal Bilimler Dergisi 2016-26/1}

$\mathrm{Bu}$ alıntıda anadil talebi, güçlü ve meşru dayanakları ile dillendirilirken, özerklik ve federatif yönetim konusunda aynı kararlılık gözlemlenmemektedir. Özellikle özerkliğin, federatif bir yönetim biçimi olarak kodlanması durumunda bu modelin arzulanmadığı anlaşılmaktadır. Burada kabul görülebilecek özerklik modeli, ağırlıklı olarak yerel yönetimlerin güçlendirilmesidir.

Ayrıca bazı korucuların bu çerçevede dile getirdikleri görüşleri şu şekildedir:

"Anadilin unutulmasinı istemiyoruz. Bu nedenle bu konuda birtakım girişimler yapılmalıdır. Elbette önemli kararlar merkez tarafindan alınmalıdır. Ancak bölge de bazı konularda kendisini yönetebilmelidir."(3. Görüşmeci)

"Anadilde ĕgitimin kesinlikle olmasını isterim. Benim çocuğum anadilini bilmeli ve anadilinde ĕgitim alabilmelidir. Özerkliğe karşıyım. Halkın önemli bir bölümü de bunun ne olduğunu bilmez. Böyle bir durumda böyle bir talep kötü sonuçlar doğuracaktır." (4. Görüşmeci)

"Elbette ki, anadilde eğitimin olmasını istiyorum. Çocuklarımız kendi dilleri ile eğitim yapabilmeli, dilimiz yaşayabilmelidir. Özerklikten kasit nedir, ne getirir, ne götürür tam olarak bilmiyorum. Ancak bana göre şimdiki yapr iyi ve devam etmelidir." (5. Görüşmeci)

"Kürtçe köklü bir dildir. Elbette Kürtçeyle de eğitim verilebilir. Hem belki bölgedeki eğitim seviyesi de yükselir. Özerklik ise şart değil. Olsa da olur olmasa da olur." (6. Görüşmeci)

Yukarıdaki alıntılardan da görüldüğü gibi korucular ağırlıklı olarak anadilin özgür kullanımı ve anadilde eğitime ilişkin talepleri daha net olarak dile getirmişlerdir. Ancak gerek içeriğinin bilinmemesi, gerek ülkede bir bölünme yaratabileceği korkusu, gerekse hâlihazırdaki mevcut pozisyonun daha iyi olduğu yönündeki kanaatler, özerklik talebi konusunda daha olumsuz değerlendirmeler yapmalarına yol açmıştır.

Aşağıda ise demokratik özerklik talebi konusunda olumlu görüş bildiren bir kaç korucuya ait değerlendirmeler yer almaktadır.

"Kürtlerin anadilde eğitim talebinde bulunmaları normaldir. Çünkü böyle bir haklarl vardır. Özerklik de olumlu bir taleptir. Bu konuda da bu talep dikkate alınmalı ve bu hak verilmelidir."(2. Görüşmeci)

"Şimdi değil çoktan bu hak verilmiş olmalıydı. Yabancı dilde eğitim imkânı tanınıyor. Ama anadilde bu imkân tanınmıyor. Bunun mümkün olmadığını, Kürtçenin eğitim dili olmadığını söylüyorlar. Ancak Irak Kürdistan'ında Kürtçe eğitim var. Hem de üniversite eğitimi var. Burada neden olmasın. Ben de ülkenin bölünmesini istemiyorum. Ancak bölünme korkusuyla hareket etmemek lazım. Kürtler içte bă̆ımsız dışta ise bağımlı olmalıdır." (13. Görüş̧meci.

"Anadilde eğitim talebini olumlu karşıllyorum. Zaten kimsenin çocuğunu Kürtçe okullara göndereceğine de inanmiyorum. Bu talepte bulunanlar, acaba çocuklarıyla Kürtçe konuşuyorlar mı? Zannetmiyorum. Eminim Türkçe konuşuyorlardır. Yerel yönetimlerin güçlendirilmesi olabilir. Ancak sağllklı olacağını sanmiyorum. Yine de denemekte fayda var." (16. Görüşmeci)

Yukarıdaki alıntılarda, özerkliği olumlayan görüşler dile getirilmiştir. Kürt sorunun varlığını kabul eden korucuların çoğunun, anadilde eğitimin bir hak olduğu ve bu hakkın olanaklı hale getirilmesi için gerekli düzenlemelerin yapılması yönündeki talepleri, anadilde eğitimin Kürt sorunun temel bir unsuru olarak algılandığını ortaya koymaktadır. 


\subsubsection{Kürt Sorununun Varlığını Reddeden Korucuların Görüşleri}

Çok sayıda korucu, kamuoyunda Kürt sorunu olarak ifade edilen problematiğin ağırlıklı olarak dış odaklı olduğu, bu nedenle örgüt elemanlarının dağdan inmelerini sağlamak için müzakerelerin yapılması gerektiğini ileri sürmüşlerdir. Daha önceden de belirtildiği gibi Kürt sorunu kapsamında dile getirilen görüşler en çok; dil ve demokratik özerklik konularında yoğunlaşmıştır. Gerek anadilde eğitim gerekse de özerklik taleplerine karșı olduklarını belirten kimi korucuların tatar aşiretine $^{8}$ mensup oldukları, bu nedenle Kürt soruna daha olumsuz bir tutum takındıkları belirtilmektedir. Kimi korucular da, PKK örgütünün ve kürt siyasal aktörlerinin/unsurlarının anadilde eğitim ve özerklik taleplerinin zorunlu ve gerekli olmadığı yönünde görüşler dile getirmişlerdir.

"Kürt sorunu diye bir sorun yoktur. Köyümüzde etnik çeşitliliğe rağmen herkes dilini kullanabiliyor. Kürtçenin kullanılmasına engel olan şey nedir yani. Ayrıca anadilde eğitim diye tutturmuşlar. Benim dilimde (Tatarca) eğitim verilse de ben, çocuğumu eğitim dili Türkçe olan bir okula gönderirim. Çünkü öyle olmazsa iyi bir eğitim alamaz ve eğitimini ilerletme imkânı da bulamaz. Demokratik özerklik konusunda haksızlar. Eğer öyle bir yapı oluşturulursa ülke bölünebilir. Hem bu yapı içerisinde kim kendini ifade edemiyor ki? Herkes ifade edebiliyor! O zaman buna ne gerek var?"(12. Görüşmeci).

Tatar olduğunu belirten korucunun, toplum tarafindan Kürt sorunu olarak tanımlanan problemi gerçekçi bulmadığ 1 ve bu çerçevede anadil ile özerklik taleplerini reddettiği görülmektedir.

“Çocuğumun Kürtçe öğrenip öğrenmemesi sikıntı değildir. Öğrenmese de olur. Kürtçeyi biz köyümüzde zaten kullanıyoruz. Ayrıca Kürtçe dünyada çok kullanılan bir dil de değildir. Demokratik özerklik tartışllabilir. Bana göre sorunun çözümünde bir etken olabilir. Olayların yatıștırılması konusunda fayda sağlayabilir." (11. Görüşmeci)

"Evimizde kendi dilimizi konuşuyoruz. Okulda tek dilde eğitim verilmeli çünkü daha sağllkl bir sistem olur. Türkiye'de başkanlık sistemi oluşursa başka bir sisteme ihtiyaç kalmaz, daha adil bir siyasi yapı olur. Çünkü böyle bir durumda, eyalet sistemi oluşturulur. Bana göre bu sistem daha adil olacaktır."(14. Görüşmeci)

Yukarıya alınan alıntılarda, anadilde eğitim talebinin gereksizliği iki nedene bağlanmaktadır. Birinci neden, çocukların köylerinde anadillerinde konuşabildikleri ve dillerini öğrenebildikleridir. $\mathrm{Bu}$ çerçevede bu koruculara göre anadilde eğitime gerek yoktur. İkincisi ise, anadilde eğitimin çocukların öğrenim hayatlarında olumsuz etki yaratacağı gerekçesidir. Kürtçe dilinde eğitimin çocuklarını eğitimde geri bırakabileceği düşüncesi hâkimdir. Bir anlamda gerek Kürtçenin hâlihazırdaki konumu gerekse eğitim dili açısından taşıdığı nitelik açısından kabul edilemez olarak değerlendirilmektedir.

Yapılan görüşmelerde Kürt sorununun varlığını kabul etmeyen korucular arasında üç bakış açısı öne çıkmıştır.

1. Kürt sorunun varlığını tümüyle red eden yaklaşım. Bu grupta yer alan korucular, Türkiye'de etnik temelde bir kimliksel sorunun yaşanmadığı, Kürtlerin kendi dillerini kullanabildikleri ve etnik kimlikten kaynaklanan temel hak ve özgürlükleri kullandıklarını ileri sürmüşlerdir. Korucular içerisinde küçük bir azınlığı teşkil eden bu koruculara göre Türkiye'de 30 yılı bulan çatışmanın çok haklı gerekçeleri bulunmamaktadır. Bu çerçevede örgüt bünyesinde yer alanlar da, örgüt tarafindan manipüle edilmiş gençlerdir.

\footnotetext{
${ }^{8}$ Türk kökenli aşiret
} 


\section{F.Ü. Sosyal Bilimler Dergisi 2016-26/1}

2. Sorunu, dış ülkelerin PKK örgütü üzerinden Türkiye'deki emellerini gerçekleştirme çerçevesinde ele alan yaklaşım. Bu kategoride yer alan korucular, PKK örgütünün, Kürt sorunun çözümünün bir parçası olarak değil, bizatihi örgütün kendi başına bir sorun teşkil ettiğini dile getirmişlerdir. Onlara göre, PKK örgütü genelde dış ülkelerin (özellikle İsrail, Ermenistan gibi) politikalarına hizmet etmekte ve onlar tarafindan kullanılmaktadır.

3. Kürt ve PKK sorununu, ağırlıklı olarak ekonomik bir sorun olarak gören yaklaşım. Bu koruculara göre, Kürt sorunun temelinde bölgenin ekonomik geri kalmışlı̆̆ yatmaktadır. Bu grupta yer alanlar, sorunun önemli ölçüde etnik bir kimlik arayışına evrildiğini ve siyasallaştı̆̆ını ancak bölgenin ekonomik sorunlarının giderilmesi ile birlikte sorunun şiddetinin azalacağını düşünmektedirler. Bu şekilde düşünen korucular, demokratik hak arayışı taleplerinin karşılanması, bölgedeki yatırımların arttırılması ve istihdam sorunlarının giderilmesi gibi bölgede ekonomik yatırımların ve istihdam olanaklarının artırılması ile sorunun şiddetinin azalacağını belirtmişlerdir.

Yukarıda belirtilen yaklaşımlar, geçmiş dönemlerde Kürt sorunun varlığını reddeden resmi ideolojik politikalar/söylemler ile paralellik arz etmesi açışından dikkat çekicidir. Sorunu, Kürt sorunu olmaktan öte bir terör sorunu olarak gören bu korucuların yaklaşımı, anadilde eğitim ve özerklik gibi PKK örgütü ve Kürt siyasal aktörlerinin dile getirdikleri talepler ile bir karşıtlık içerisindedirler. Hiç kuşkusuz, korucuların PKK örgütünün özerklik yönündeki taleplerine karşıt yönde görüş belirtmelerinin önde gelen birkaç nedeni vardır: Birincisi, sahici olarak bazı korucuların anadilde eğitim ve özerklik taleplerinin ülkenin bütünlügüne zarar verebileceği kaygısına sahip olmalarıdır. Yapılan görüşmelerde bazı korucular, anadilde eğitimin ve özerklik taleplerinin ülkenin bütünlüğüne zarar verebileceği yönündeki kaygılarını dile getirmişledir. İkincisi, bir paramiliter güç olarak korucuların Türk devletinin temel paradigması içerisinde mücadele etme pozisyonuna sahip olmalarıdır. Üçüncüsü ise, bölgede özerkliğin inşa edilmesinin aynı zamanda kendilerinin de tasfiye edilmeleri ve örgüt tarafından cezalandırılabilme ihtimalini taşımasıdır. Diğer bir ifade ile korucuların büyük bir kısmının demokratik özerkliğe eleştirel ve mesafeli yaklaşmalarının bir nedeni, demokratik özerklik modelinde kendilerine yönelik demokratik ve hoş görülü bir yaklaşımın olamayacağı konusunda duydukları tedirginliktir. Hâlihazırda, PKK örgütünün ve Kürt oluşumlarının, STK'larının ve medyasının koruculara yönelik menfi propagandaları, köy korucularının toplum tarafından ciddi bir şekilde dışlanma riskiyle karşı karşıya gelmelerine yol açmıştır. Bu nedenle, korucuların toplum tarafından olumsuzlanan ve dışlanan statüleri, PKK veya Kürt aktörlerinin yönetimi altında daha ciddi bir şekilde sorun teşkil edecektir.

PKK örgütü ile Geçici Köy Kurucuları arasında uzun süredir devam eden çatışmalar ve PKK tarafından gerçekleştirilen korucu infazları, korucular arasında da ciddi bir tedirginlik ve hoşnutsuzluk oluşturmaktadır. Kürt sorunu çerçevesinde dile getirilen talepler günümüzdeki kadar kitlesel ve meşru bir talebe dönüşmediği geçmiş dönemlerde ağırlıklı olarak ekonomik kaygılarla kabul edilen koruculuk sisteminin günümüzde sürdürülemez olduğu tezi korucular tarafindan da kabul görmektedir. Bu nedenle, Kürt sorunun varlığı konusunda olumsuz yaklaşımlara sahip olan korucular bile, bu sorunun çözümünden yana bir tutum içerisindedirler.

Sonuç olarak Kürt sorunun varlığını kabul etmeyen her üç yaklaşımı benimseyen korucuların, hükümetin geçmişteki demokratik reformları ve barış müzakereleri sürecindeki girişimlerini olumlu değerlendirdikleri ve bu çatışmaların ivedilikle son bulmasından yana görüşler ileri sürdükleri tespit edilmiştir. Çok az korucu da, Kürt sorununun varlığını kabul etmemekle birlikte, bölgede uzun bir süredir devam eden çatışmaların son bulması adına demokratik özerkliğin bile tartışılabileceğini, bunun çatışmaların durmasında faydalı olabileceği görüşünü ileri sürmüşlerdir.

\subsubsection{Korucular PKK Örgütünü Nasıl Görüyorlar?}

Doğal olarak, PKK örgütüne karşı silahlanmış olan ve aynı şekilde zaman zaman devlet güvenlik güçleri ile birlikte örgüt mensuplarına karşı operasyona çıkan köy korucularının PKK örgütü ile karşılıklı olarak olumlu bir bakış içinde olmaları beklenemez. Bu nedenle PKK ve onların bileşenleri, köy korucularını kendilerine karşı konumlanmış ve düşmanla işbirliği 
içeresinde hareket eden hain/işbirlikçi ve paramiliter bir güç olarak görmektedir. PKK örgütü ile korucular arasında yıllarca süren çatışmalar ve yaşanan can kayıpları, her iki güç arasında amansız bir düşmanlık oluşturmuştur.

Koruculara, 'PKK sizin için nasıl bir anlam ifade ediyor?' şeklinde bir soru yöneltilmiştir. Korucuların \% 38'i, "bazı odakların ve dış güçlerin kullandığı bir örgüt”, \% 30'u "terörist bir örgüt", \% 20.4'u "Kürt halkının hakları için mücadele eden silahlı bir örgüt" olarak tanımlarken, \% 7'si de bu soruya yanıt vermek istememişlerdir. Korucuların \% 4. 4'ü de "diğer" (kan ve gözyaşını andıran ve kendi devletini kurmak isteyen bir örgüt olduğu) seçeneğini işaretlemişlerdir. $\mathrm{Bu}$ bulgular, korucuların yaklaşık olarak \% 70'inin, PKK örgütüne yönelik değerlendirmelerinin olumsuz olduğunu ortaya koymaktadır. Bu, ağırlıklı olarak PKK'nın “terör örgütü” ve "dış güçler tarafindan kullanılan" bir örgüt şeklinde değerlendirdikleri anlamına gelmektedir. Bu saptamalarda şaşırılacak her hangi bir durum söz konusu değil. Assl şaşırtıcı olanı, hiç kuşkusuz, korucuların yaklaşık olarak, \% 20.4'ünün PKK örgütünü, "Kürt halkının hakları için mücadele eden silahlı bir örgüt" olarak tanımlamış olmalarıdır. Bu kategoride yer alan korucuların PKK örgütüne olan bu olumlu bakışın, PKK'yı meşru ve haklı gören bir anlayışı teşkil ettiği reddedilemez. Burada daha çarpıcı olan diğer bir sonuç ise, PKK'yı Kürt hakları için bir örgüt olarak tanımlayan korucuların yaklaşık olarak \% 86'sının bir şekilde, bölgenin çatışmalı süreci içerisinde can kaybını yaşamış olduklarını ifade etmiş olmalarıdır. Bu nedenle, yakın aile ve akraba bireylerini kaybeden korucuların bu çatışmaların kendilerine bir bedel ödettiğini düşündükleri söylenebilir. Ancak burada önemli olan, yaşanan can kayıplarının güvenlik güçlerinden mi yoksa örgüt elemanlarından $\mathrm{m} ı$ kaynaklandığı hususunun bilinmesidir.

Diğer bir husus ise, korucu olanların aile ve akraba bireyleri içerisinden de PKK örgütüne destek veren, örgütün dağ kadrosuna katılan veya Kürt partileri ve STK'ları içerinde faaliyet yürüten bireylerin varlığıdır. Bu katılmalar ve iştirakler, PKK'ya olan olumsuz bakışın değişmesinde etkili olmuştur. PKK'yı, "Kürt halkının hakları için mücadele eden bir örgüt" olarak gören korucuların, PKK konusundaki görüşlerinin de zamanla değiştiğini de göstermektedir. Çünkü koruculuğu kabul etmeden önce PKK konusunda olumlu bir bakışa sahip olmak, koruculuğu kabul etmeyi zorunlu olarak reddetmeyi- eğer PKK ile anlaşmalı bir durum söz konusu değilsegerektirmektedir. Bazı korucuların şu anki pozisyonlarını veya yaptıkları görevi "şerefsizlik" olarak tanımlamaları da aslında, yaşadıkları çelişkiyi göstermektedir. Kendilerine yönelik bu alımsız algının, Kürt ve PKK bakışının olumlu olmasında etkisi olduğu söylenebilir.

"PKK olmasaydı Kürtlere bu kadar hak tanınmazdı. Eskiden insanlar evlerinde bile Kürtçe müzik dinleyemezken şimdi telefonda sokakta rahatça dinleyebiliyor. PKK Kürtlerin hakkını savunan bir örgüttür. Çanakkale savaşında Kürtler de vardı. $O$ halde Kürtlerin de bu devlette hakkı var. İste PKK bu haklarl istiyor.” (13. Görüşmeci)

Kürtlerin şu an sahip oldukları bazı hakların PKK'nın mücadelesi sonucunda elde edildiği inancı Kürtler arasında yaygındır. Kürtlerin etnik bir ulus olduğu ve etnik ulus olmaktan dolayı bazı haklara sahip olmaları gerektiği yönündeki bilincin gelişimi ve devletin Kürt sorunu çözümü konusunda gerçekleştirdikleri reformların, devlet güçleri ile olan mücadele sürecinde PKK'nın başarısı olduğu varsayılmaktadır. Özellikle, Kürtçe konuşma, Kürtçe müziğin/yayının önündeki engellerin kaldırılması ve Kürtçe yayın yapan TV.'nin kurulması gibi Kürtçe dilinin kullanılmasının önündeki engellerin kaldırılması, örgütün mücadelesi sonucunda elde edilen haklar olduğu vurgusu yapılmaktadır. Bu anlayışın bir benzerinin yukarıdaki korucunun ifadesinde de kendini açığa vurmuştur. Bu yaklaşım, PKK örgütünün varlık nedenini ve mücadelesini haklılaştıran bir işlev görmektedir. Bazı korucular da özellikle bu konuda görüş bildirmekten kaçınmışlardır.

PKK örgütüne karşı olumsuz değerlendirmelerde bulunan korucular da görüşmelerde ağırlıklı olarak PKK'nın, terörist bir örgüt olduğu ve Türkiye ile ilgili hesapları olan ülkeler tarafindan kullanıldığı temasını öne çıkartmışlardır. Konuya ilişkin olarak burada görüşmecilerden sadece üç kişinin görüşü aşağıya alınmıştır: 
"Vahşet yapan, babamın ve birçok masumun katili bir örgüt. Bunlar dış güçlerin piyonudur. Ortadoğu'nun düşmanı olan batılı güçlerin oyunlarına gelmişlerdir. Din düşmanlı̆̆ yapıyorlar." (3. Görüşmeci)

"PKK deyince benim aklıma gelen tek şey kan ve gözyaşı. Bazı dış güçlerin etkisi altında olduğu için böyle birtakım işlere girişmişler. Ancak örgüt üyelerinin önemli bir bölümü, bu durumun farkında değil. Kürt halkının hakları için savaştıklarını sanıyorlar." (4. Görüşmeci)

"PKK deyince ülkenin bütünlügüne kast eden, halkın arasina fitne fesat sokan kimseler, uyuşturucu kaçakçıllğı, mayın ve ölüm geliyor benim aklıma. Cahilliklerinden dolayı dağa çıktılar. Başkalarının maşası oldular.” (15. Görüşmeci)

"Kürtlerin haklarını savunmak için savaştıkları propagandasını yapan bir örgüt. ... Kürtlerin haklarını savunmak ve bu hakları elde etmek istedikleri propagandasını yapıyorlar ama gerçek amaçları bu mu, yoksa bazılarının söylediğ $i$ gibi dış güçlerin maşası mı? Bilemiyorum." (1. Görüşmeci)

“Doğu ve Güneydoğu'nun düşmanı olduğu aklıma geliyor. Kendileri için hedefledikleri bir amaçları, hele de Kürtlükle hiç alakaları yoktur. Ayrıca, kimin için çalıştıkları da belli değil." (9. Görüşmeci)

Anlaşılan PKK örgütünü terörist ve dış ülkelerin maşası olarak gören korucular, PKK'nın Kürt halkının hakları için mücadele etmediği kanaatindedirler veya en azından bazı korucular, PKK'nın Kürt halkının haklarını savunduğu propagandası yaptığı, ancak gerçek amaçlarının bu olmadığı, halkı kandırıp kullandıklarını düşünmektedirler.

"PKK sizin için nasıl bir anlam ifade ediyor?" sorusuna korucuların \% 8,8'inin yanıt vermek istememelerinin anlaşılır nedenleri vardır. Bu grupta yer alan korucular, görüşmeyi gerçekleştiren araştırmacıya bu konuda yapacağı açıklamanın deşifre olabileceği kaygısıyla yanıtlamak istememişlerdir. Korucuların, burada hem PKK hem de devlet güçleri tarafindan çekindikleri söylenebilir.

Koruculara, kendilerinin PKK ile mücadele etme konusundaki görüşlerini belirlemek için, "PKK ile mücadeleyi doğru buluyor musunuz?" şeklinde bir soru yöneltilmiştir. Bu soruya korucuların \% 48'i “doğru bulduklarını", \%52'si “doğru bulmadıklarını” belirtmişlerdir. PKK ile mücadeleyi doğru bulmadıklarını belirten korucular, mücadeleyi kendilerinin değil, asker ve polis gibi devletin güvenlik güçlerinin yapması gerektiğini belirtmiş olmaktadırlar. İller bazında dağılımlara bakıldı̆̆ında; Muş, Bingöl, Batman ve Van'a kıyasla Diyarbakır, Mardin ve Hakkari illerinde ikamet eden korucuların örgüt ile mücadele gerekliliği konusunda daha az istekli oldukları saptanmıştır. Bu illerde mücadele konusunda daha az bir isteğin olmasının, söz konusu illerde örgüt mensuplarıyla daha sıklıkta çatışmaların yaşanması ve aynı şekilde koruculara yönelik halk tarafından daha olumsuz bir bakışın olması ile ilintili olabilir. Özellikle korucular arasında can kaybının yaşanmış olması veya örgütün koruculara yönelik saldırıları veya saldırma riski gibi unsurlar, korucuların PKK mensuplarıyla silahlı bir çatışmaya girme veya operasyona çıkma konusunda daha az istekli kıldığı bir gerçektir.

Örgüt ile silahlı mücadeleye girme konusunda olumsuz görüş bildiren korucular ağırlıklı olarak; PKK ile mücadele etmenin güç oluşu ve yaşam açısından risk oluşturduğunu belirterek PKK ile savaşmanın kendilerinin PKK'nın silahlı saldırısına açık hedef haline getirdiklerini dile getirmişlerdir.

"Kimse canından ve malından olmak istemez, ama biz çocuklarımızın ve köyümüzün güvenliğini sağlamak için canımızı ve malımızı ortaya koymuşuz. Bize ve köyümüze zarar verebilirler (14. Görüsmeci). 
"PKK ile mücadele etmek herhangi bir can güvenliği olmadan yaşamaya alışmaktır."(16. Görüşmeci). "PKK ile mücadele etmek demek operasyonlardan evine să̆ dönme garantisinin olmaması demektir."(17. Görüşmeci)

Yukarıya alınan alıntıda korucuların, çatışmalarda örgüt mensupları tarafından öldürülebilecekleri ve bu nedenle can güvenliği kaygılarını taşıdıkları görülmektedir.

Bazı köy korucuları, devlet güçlerinin bile örgüt mücadelesinde zorlandıkları, onlarla başa çıkamadığ 1 bir durumda kendilerinin PKK ile mücadele etmede başarılı olmalarının mümkün olamayacağ1 düşüncesinde oldukları gözlenmiştir. Hiç kuşkusuz örgüt mensupları tarafından saldırıya uğrayan veya yakın aile bireylerini kaybeden bazı korucuların da, örgüt ile mücadele etmede istekli oldukları dikkatten kaçmamıştır. Bunu yanı sıra yabancı güçler tarafindan kullanıldıklarını düşünen korucular, örgüt mensuplarıyla mücadele etmede daha istekli oldukları ancak Kürtlerin hakları için savaşan bir örgüt olarak gören korucuların da çatışmaya daha mesafeli ve eleştirel yaklaştıkları tespit edilmiştir. Köy korucularını PKK ile silahlı mücadelede aktif olarak görev alma konusundaki tutumlarının olumlu veya olumsuz olacağı hususunda, geçmişte saldırıya uğramak, yakınlarının yaralanması veya ölmesi ve Kürt sorunu içerisinde PKK örgütünü nereye oturttukları (yabancı güç odakları tarafından kullanılma) gibi faktörler etkili olmaktadır.

\subsubsection{Bazı Korucular Niçin PKK Örgütüne Destek Vermektedir?}

Yukarıda da belirtildiği gibi korucuların yaklaşık olarak \% 20'si, PKK örgütünü Kürt halkının hakları için mücadele eden bir örgüt olarak tanımlamışlardır. Bu anlayış, PKK örgütünün haklılığını onaylayan bir bakış açısını yansıtmaktadır. Hiç kuşkusuz örgüte bu olumlu bakış, zaman zaman örgüte yardım ve yataklık etmeye kadar uzanabilmektedir. Bu da korucular arasında PKK örgütüne destek veren korucuların olduğu anlamına gelmektedir. Bu hususu, İçişleri Bakanlığı Verileri de doğrulamaktadır.

İçişleri Bakanlığı verilerine göre, 1985-2003 y1lları arasında suç işledikleri gerekçesiyle haklarında işlem yapılan 4804 korucudan, 2376' 1 çeşitli adli suçlardan, 2375'i ise PKK'ya yardım ve yataklık suçlarından işlem yapılmıştır (bkz. Balta ve Akça, 25-26). Haklarında işlem yapılan korucuların önemli bir oranının, PKK örgütüne yardım ve yataklık yapma suçundan olması son derece dikkat çekicidir.

Çalışma kapsamında, koruculara "bazı korucuların PKK'ya yardım ve yataklık etmelerini nasıl değerlendiriyorsunuz?” şeklinde bir soru yöneltilmiş̧tir. Korucuların büyük bir kısmı örgüte yardım edenlerin varlığını, örgütten çekinme veya korkmak ile gerekçelendirmişlerdir. Bu görüşü dile getirenler, korucuların örgüte karşı kendilerini sürekli olarak koruyamadıklarını ve bu nedenle onlarla anlaşma yolunu seçtiklerini ileri sürmüşlerdir: Korucuların anlatımlarında "yaşamsal zorunluluk" dışında başka faktörler de vurgulanmıştır:

"Yardım ve yataklık edenlerin büyük çoğunluğu bunu mecbur oldukları için yapmaktadır. Çünkü kendilerini her zaman örgüte karşı koruyamazlar. Bu nedenle PKK'ye yardım ediyorlar. Bazı korucular ile örgüt arasında akrabalık ilişkileri olması da yardım ve yataklığın bir başka nedenidir. Çünkü birçok köyde akrabalardan biri baskılarla korucu olmak zorunda kalırken, bir diğer akraba da örgüte katılmıştır." (5. Görüşmeci)

"Asker ve polis gibi güvenlik güçlerinin hemen ulaşmasında sikıntı olan yerlerde, korucular, örgütün tehditlerine boyun ĕgmek zorunda kallyor. Ancak, bunların içinde, bazı gönüllü olarak yardım edenler ve örgütle aynı amacı güden korucular da var."

"PKK'ya yardım ve yataklık yapanlar, zorla korucu yapılmış kişilerdir. Zaten bu insanların fikri budur. Fikri bu olanlara zorla koruculuk yaptırırsanız sonucu da bu olur." (8. Görüşmeci) 
"Devlet, ne kadar PKK sempatizanı varsa hepsini korucu yaptı. Örneğin 1990 'l y yllarda korucu olanlar, istemeden, devletin zoruyla korucu oldu." (16. Görüşmeci)

"Bazı korucular baskı gördüler, zorla korucu yapıldılar. Ayrıca bu korucular dışlandılar. Dışlandıkça da PKK'ya yanaştılar.” (18. Görüşmeci)

Yukarıdaki anlatımlarından hareketle korucuların PKK'ya yardım ve yataklık etmelerinin nedenleri 4 kategori içerisinde ele alınabilir:

1. PKK örgütünden duyulan korku. Korucuların, örgüt elemanları tarafindan gerek görev yaptıkları bölgelerde, gerekse yolculuk esnasında veya operasyon dönemlerinde saldırıya maruz kalma ve hayatlarını kaybetme riskleri her zaman bulunmaktadır. Öyle ki korucular, kırsal yerleşim yerlerinden ilçe ve şehir merkezine bile gitmekte zaman zaman kaçınmaktadırlar. Çünkü geçmişte çok sayıda korucu bu şekilde saldırıya uğrayıp öldürülmüşlerdir. Özellikle, güvenlik birimlerine uzak yerleşim bölgelerindeki korucuların ve güvenlik güçlerinin ulaşmakta güçlük yaşadığ 1 bölgelerdeki korucuların PKK saldırılarına maruz kalma riskleri daha yüksektir. Aynı şekilde, korucu sayısı açısından daha az güçlü oldukları ve geçmişteki husumetlerden dolayı örgütün hedefinde olan bazı korucuların PKK saldırılarına karşı koyacak güçlerinin daha zayıf olduğu söylenebilir. $\mathrm{Bu}$ sebeplerle, öldürülme ve saldırıya uğrama endişesi yaşayan bazı korucular, PKK'nın birtakım isteklerine boyun eğmek veya isteklerini karşılamak durumunda kalmaktadırlar.

2. Bölgede artan Kürt milliyetçiliği ve PKK örgütüne giderek artan toplumsal destek. PKK örgütünün silahlı eylem başlattığı 80 'li yılların ortası ve 90'lı yılların başına kıyasla günümüzde PKK ideolojisi daha çok taraftar kazanmış durumdadır. İlk dönemlerde ciddi bir halk desteğinden yoksun olan örgüt, zamanla ciddi bir desteğe ulaşmıştır. Bu çerçevede, örgütün milliyetçilik ideolojinin giderek daha fazla taban bulmasıyla birlikte korucular da aynı şekilde bu süreçten etkilenmişlerdir. Kitlesel protestolar, Kürt medyasının etkisi, Kürt partilerinin ve STK'larının giderek etkili olmaya başlamasına paralel olarak artan kitle desteği aynı şekilde bazı korucuları da etkilemiştir.

3. Korucu olmadan önce, örgüte sempatizanlığın veya Kürt sorununa duyarlılığın varlı̆̆ı. Bu grupta yer alan korucular, korucu olduktan sonra da PKK örgütüne karşı bakışlarında bir değişme meydana gelmemiştir. Özellikle, korucu olmaya zorlananlar, PKK’ya daha fazla sempati duydukları da söylenebilir.

4. Koruculuk mesleğine, maddi bir kazanç veya istihdam perspektifinden bakma: $\mathrm{Bu}$ kategoride yer alan bazı korucular, koruculuk sayesinde devlet görevlisi olarak maaş sahibi olmayı amaçladığı gibi aynı şekilde örgütün saldırılarından da korunmak için da örgüt veya onların siyasal aktörleri ile işbirliği içerisine girebilmektedirler.

\section{SONUÇ VE GENEL DEĞERLENDİRME}

Koruculuk sisteminin PKK örgütü ile mücadele etmek için geliştirilmiş olması ve korucular ile PKK örgütü arasında yıllarca süren çatışmalar, her ikisi arasında amansız bir düşmanlık ihdas etmiştir. Korucuların gerek güvenlik personeli ile birlikte PKK örgütü ile çatışmalara katılmaları gerekse de korucular ile örgüt arasında yaşanan çatışmalarda can kayıplarının oluşması ve gerekse de örgütün ve örgütü destekleyenlerin yıllardır korucular aleyhinde sürdürdükleri, aşağılayıcı, dışlayıcı ve itham edici dil ve propagandalar sayesinde, korucuların PKK örgütü ve Kürt sorunu konusunda, devlet ile benzer görüşlere sahip olabilecekleri tahmin edilmiştir. Ancak araştırmada, bazı korucuların (her 5 korucudan birinin) PKK örgütüne yönelik olumlu düşünceye sahip olmaları ve anadil ile özerklik konusunda örgütün ve onların siyasal aktörleri tarafindan dile getirilen görüşler ile benzer düşünceler dile getirmeleri, araştırmanın çarpıcı bir saptaması olarak dikkat çekmiştir.

$\mathrm{Bu}$ çalışmada, korucuların Kürt sorunu ve PKK konusundaki görüşlerinin tümüyle birbiriyle benzerlik arz etmediği saptanmıştır. Kimi Korucular bir Kürt sorununun varlığını kabul ederken, 
kimilerinin de böyle bir sorunun varlığını reddettikleri belirlenmiştir. Kürt sorunun varlığını kabul eden korucular genelde, cumhuriyet döneminden bu yana bir Kürt sorunu olduğunu, bu sorunun da en belirgin göstergesinin Kürt dilini kullanma yönündeki engeller olduğunu, Kürtlerin geçmişte ikinci sınıf vatandaş muamelesi gördüklerini ve asimilasyona tabi tutulduklarını ileri sürmüşlerdir. Kürt sorunun varlığını kabul eden korucuların çoğunun, anadilde eğitimi savunan yönündeki açılamaları, anadilde eğitimin Kürt sorunun temel bir unsuru olarak algılandığını ortaya koymaktadır. Kürt sorunun varlığını kabul eden korucuların öne çıkardıkları temel bir görüş ise, bu sorunun şiddet eylemleri ile çözülemeyeceği hususudur.

Kürt sorunu konusunda ifade edilen hususlar ağırlıklı olarak, anadilde eğitim ve özerklik talebinde yoğunlaşmışır. Korucuların çoğu, genelde anadilde eğitimin önündeki engellerin kaldırılması gerektiğini düşünürken, özerklik konusunda da aynı olumlu yaklaşımın olduğunu söylemek mümkün değildir. Zaten görüşülen korucular arasında özerklik modelini öne çıkaran korucuların sayısı son derece azdır. Korucuların, demokratik özerklik yönündeki taleplerinin, anadilde eğitim talebine kıyasla daha az dile getirildiği söylenebilir. Demokratik özerklik modelinin ne olduğunun bilinmemesi ve bir bölünme yaratabileceği korkusu, korucuların özerklik modeline mesafeli duruş sergilemelerinde veya karşı görüşler bildirmelerinde etkili olmuştur.

Çok sayıda korucu da, Kürt sorunun varlığını reddetmişlerdir. Kürt sorunun varlığını reddeden kimi korucular, Türkiye'de etnik kimliği ne olursa olsun herkesin, dilini kullanmakta her hangi bir engelle karşılaşmadığı ve etnik kimlikten kaynaklanan haklarını özgürce kullandıklarını ileri sürmüşlerdir. Bunlara göre 30 yıldır süren içi çatışmanın haklı gerekçeleri yoktur. Onlara göre, yaşanan çatışmalar veya PKK örgütünün varlığı, gençlerin aldatılmış olması ile açıklanabilir. Kimi korucular da, Kürt sorunundan çok bir PKK sorunun olduğunu ve bu sorunun genelde diş ülkelerin (özellikle İsrail, Ermenistan gibi) Türkiye üzerindeki emellerinden kaynaklandığı ve örgütün bu ülkelerin politikalarına hizmet etmek için mücadele ettiği etrafında odaklanmaktadır. Kimi koruculara göre de, PKK sorunun temelinde, bölgenin ekonomik geri kalmışlığı faktörü bulunmaktadır.

Köy korucularının önemli bir bölümünün Kürt sorununun varlığını kabul etmelerine rağmen, PKK örgütü hakkında olumsuz görüşler dile getirmeleri, korucuların Kürt sorunu ile PKK sorunun birbirinden ayrıştırdıklarını göstermektedir. Korucuların önemli bir oranı, PKK örgütünün dış güçler tarafından kullanılan bir örgüt (\% 68 ) olarak tanımlamışlardır. Ancak korucuların yaklaşık olarak beşte biri PKK örgütünü Kürt sorunu ile ilintili olarak ve haklı bir mücadele yürüten bir örgüt olarak tanımlamaları, son derece dikkat çekicidir. Onlara göre, Kürt sorunundaki kazanımlar örgütün mücadelesi sonucunda ele edilmiştir.

Koruculuk sisteminin oluşturulduğu tarihten bu yana korucuların PKK'ya olan bakışlarında kimi değişmeler yaşanmıştır. Özellikle PKK örgütünün çok daha etkin olduğu sınır bölgelerindeki yerleşim yerlerinde görev yapan korucuların PKK örgütü elemanları ile temas etmeleri ve örgüt sempatizanlarının yoğun saldırılarına, eleştirilerine ve dışlanmalarına hedef olmaları onların PKK örgütüne daha olumlu yaklaşım geliştirmelerine ve yer yer onlarla işbirliği içine girmelerine yol açmış olabileceği söylenebilir. Bu nedenle korucular arasında örgütün Kürt sorunu konusundaki argümanlarını haklı bulan veya bu söylemleri dillendiren bir korucu grubundan söz etmek mümkündür. Ayrıca, örgüt ile işbirliği içerisine giren ve bu sayede can güvenliğini garantiye alan çok az da olsa bir korucu varlığından da söz etmek mümkündür. Bu çerçevede, önemli sayıda korucular hakkında, örgüte yardım ve yataklık suçlarından işlem yapılmıştır. Korucuların, örgüte destek vermelerinin nedenleri arasında; örgütün saldırılarından duyulan korku, düşünsel olarak örgüte duyulan sempatizanlık, Kürt milliyetçiliği konusunda oluşan bilinç ve örgütle anlaşma yapma gibi etkenlerin rol oynadığ söylenebilir.

Korucuların Kürt sorunu ve PKK örgütü konusunda farklı görüşlere sahip olmaları, koruculuğun kabul edilme nedenleri ile ilintili olan bir yanı da bulunmaktadır. Bu çerçevede, koruculuğun gönüllü veya zorunlu olarak kabul edilme biçimine göre, PKK ve Kürt sorunu konusundaki yaklaşımların da farklılaşmasına yol açmış olabilir. Hiç kuşkusuz burada dikkat 


\section{F.Ü. Sosyal Bilimler Dergisi 2016-26/1}

edilmesi gereken önemli bir husus da, PKK örgütüne olan desteğin artmasına veya örgütün taleplerinin Kürtler arasında giderek kabul görmesine bağlı olarak, korucuların da PKK ve Kürt sorunu konusundaki görüşlerinin ilk dönemlere kıyasla giderek değişmeye başlamış olmasıdır. İlk dönemlerde, PKK örgütünün Kürtler konusundaki argümanlarını ülkeyi bölen, ayırımcı ve dolaysıyla tehlikeli ve olanaksız gören bazı korucular, gerek Kürtlerin örgüte olan desteklerinin artışına bağlı olarak gerekse de Türkiye'de; Kürtler konusunda devletin inkarcı ve dışlayıcı politikalarının terk edilmesi, hakim ulus paradigmasından vazgeçilmesi ve gerekse bu alanda demokratik reformların gerçekleştirilmesi gibi gelişmeler sayesinde korucuların da zihin dünyasında da ciddi dönüşümler yaşanmıştır.

Korucuların PKK örgütüne yaklaşımlarında, görev yaptıkları bölge, can kaybı yaşayıp yaşamadıkları, örgütün saldırısına maruz kalma riski, sempatizanların ve örgüt mensuplarının yoğunluğu, yakınlarından örgüte katılanların olup olmadığı, geçmişte örgüte nasıl baktıkları, örgüt elemanları ile her hangi bir temas ve işbirliğinin gerçekleştirilip gerçekleştirilmediği gibi hususlar etkili olduğu söylenebilir.

\section{KAYNAKÇA} Lanham

Barkey, Henri ve Graham Fuller (1998), Turkey’s Kurdish Question, Rowman \& Littlefield Publishers,

Fuller, Graham ve Henry Barkey (2011), Türkiye'nin Kürt Meselesi. İstanbul: Profil Yayınc1lı Yayınları.

İmset, G. İsmet (1993). PKK Ayrılıkçı Şiddetin 20 y1lı (1973-1992). Ankara: Turkish Daily News

Jandarma Genel Komutanlığı (03.04.2012) Kişisel Yazışma ile Alınan Veriler

Kurban, Dilek (2010). "Bir Güvenlik Politikası Olarak Korucu Sistemi”. Almanak Türkiye 2006-2008 içinde (Der: Ali Bayramoğlu ve Ahmet İnsel ), s. 253-259. İstanbul: TESEV Yayınları.

Önder, M. Seyman (2013), Geçici Köy Korucuları Üzerine Sosyolojik Bir Araştırma, Fırat Üniversitesi, Sosyal Bilimler Enstitüsü, (Yayınlanmamış doktora tezi), ELazı̆̆

Marcuse, Aliza (2009), Kan ve İnanç: PKK ve Kürt Hareketi (A. Alkan çev.), İstanbul: İletişim

Paker, E. Balta ve İsmet Akça (2013), “Askerler, Köylüler ve Paramiliter Güçler: Türkiye’de Köy Koruculuğu Sistemi”, Toplum ve Bilim Dergisi, Sayı:126, 734

Tapan, Berivan (2007). Terörün Bekçileri Hamidiye Alaylarından Günümüze Koruculuk. İstanbul: Güncel Yayıncilık.

Tüysüz, Nur (2014), "Geçici Köy Koruculuğu Sisteminin Toplumda Yarattığı Dönüşüm ve Korucu Olmanın Kişisel Gerekçelendirmeleri”, Toplum ve Kuram Sayı: 9, 177-202 